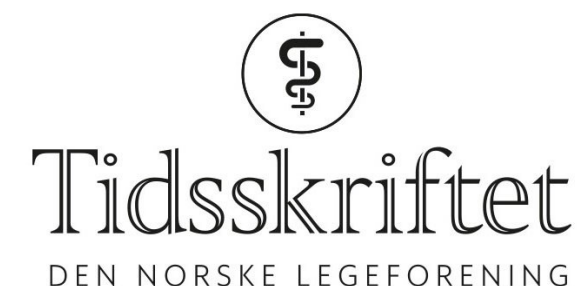

DEN NORSKE LEGEFORENING

\title{
Jarl A. Kahn
}

MINNEORD

HANS IVAR HANEVIK

ARNE SUNDE

VIDAR VON DÜRING

Dr.med. Jarl A. Kahn (født 9. mai 1943) døde 16. mai 2020 etter et kort sykeleie, 77 år gammel. Han var en av grunnleggerne av norsk fertilitetsbehandling.

Dr. Kahn vokste opp i Trondheim, studerte medisin i Groningen og ble lege ved Kvinneklinikken på Regionsykehuset i Trondheim i 1976. Etter at verdens første prøverørsbarn ble født i England i 1978, ba professor Kåre Molne ham om å starte prøverørsbehandling av ufrivillig barnløse. Budsjett fantes ikke, men Kahn fikk tilgang til noen rom på sykehuset, et par spann med rosa veggmaling og litt lønnsmidler. Så samlet han fagfolka som skulle komme til å stå bak Norges første prøverørsbarn. Mona Susanne ble født i 1984, og da Gro Harlem Brundtland senere holdt tale om de to store medisinske begivenhetene i landet det året, gjaldt det Norges første hjertetransplantasjon i Oslo og prøverørsbarnet fra Trondheim.

Over arbeidet som Kahn ledet, lå det en ekte pionerånd. Det fikk fram det beste i ham: oppfinnsomhet, lagbygging, omsorg for dem rundt seg og standhaftighet i de kontroversielle spørsmålene som prøverørsbehandling er omgitt av. Dessverre døde han før eggdonasjon ble et tilbud i Norge, men han så at det var like før.

Kahns sykehusavdeling vokste, og det første barnet i Norden etter tining av et befruktet egg kom derfra i 1987. Han ble akademisk merittert i inn- og utland, men vendte alltid tilbake til de ufrivillig barnløse pasientene. Vi som så ham i aksjon husker særlig evnen til å få hver pasient til å føle seg som den viktigste i verden.

Da Kahn senere flyttet til Telemark og grunnla sin neste fertilitetsavdeling i 2002, fikk også den rosa venterom. Også denne avdelingen vokste seg sterk under hans ledelse. Han var overlege ved Sykehuset Telemark fram til han ble pensjonert, og i 2013 ble han utnevnt til ridder av 1. klasse av St. Olavs Orden for sin innsats.

Våre tanker går til hans nærmeste.

På vegne av fagmiljøet 
(ㅇ) Tidsskrift for Den norske legeforening 2020. Lastet ned fra tidsskriftet.no 